Uludag Univ. J. Fac. Vet. Med. 32 (2013), 2: 19-24

\title{
Comparison of Different Sample Types for Salmonella Detection From Chicken Layer Breeder Flocks
}

\author{
Serpil KAHYA ${ }^{1}$
}

\author{
Ayşsegül EYİGÖR²
}

Geliş Tarihi: 13.03 .2014

Kabul Tarihi: 28.04.2014

\author{
K. Tayfun ÇARLI $^{1}$
}

\begin{abstract}
The object of this study was to detect Salmonella from different chicken samples in same flocks to compare sample types for Salmonella detection by both International Organization for Standardization Method 6579:2002/Amd 1:2007 (ISO) and as molecular by a polymerase chain reaction (PCR) method. Salmonellosis is a zoonotic infection and apart from this, infection can be transmitted via vertically to embryo, and this is very important for breeding flocks. A total of 115 samples, comprised of 451 individual samples each pooled into 3 , 4, 5 and 6 including 14 drag swabs, 28 pooled wet faeces, 11 pooled embryonated chicken eggs, 62 pooled cloacal swabs, were collected from 14 chicken layer breeding flocks, and tested by culture method (ISO 6579) and conventional PCR. Overall Salmonella infection rate in chicken layer breeder flocks by PCR and culture was $18.2 \%(21 / 115)$. According to sample type, Salmonella rate in culture positive samples were: $0 \%(0 / 14)$ in drag swabs, $90.9 \%$ (10/11) in embryonated chicken eggs, $21.4 \%(6 / 28)$ in wet faeces, $8 \%(5 / 62)$ in cloacal swabs.

PCR results were in $100 \%$ agreement (100\% sensitivity and specificity) with culture results. We determined Salmonella rate in 14 chicken layer breeder flocks by using culture and PCR methods, and the use of embryonated chicken eggs and wet faeces samples, respectively in Salmonella detection would yield reliable results. These results indicate that Salmonella screening can be done together with different types of sample. And the most reliable and high results were taken from embryonated chicken egg samples for layer breeding poultry. As a conclusion, Salmonella infection seems to be the major problem in poultry flocks in Turkey, and both conventional culture method and PCR methods were found sensitive for the detection of Salmonella from poultry with different types of sample.
\end{abstract}

Key Words: Salmonella, chicken layer breeder flock, polymerase chain reaction (PCR), culture, zoonosis, different sample types.

\section{Damızlık Yumurtacı Tavuk Sürülerinden Salmonella Tespiti için Farklı Örnek Tiplerinin Karşılaştırılması}

Özet: Bu çalışmanın amacı, aynı kümeslerden alınan farklı örnek tiplerinin, hem Uluslararası Standardizasyon Teşkilatı 6579:2002/Amd 1:2007 (ISO) kültür metotu hem de moleküler olarak polimeraz zincir reaksiyonu (PCR) ile çalışılarak Salmonella teşhisi bakımından karşılaştırılmasıdır. Salmonella zoonoz bir enfeksiyondur ve ayrıca vertikal geçiş özelliğinden civcivlere geçebileceğinden dolayı, özellikle damızlık kanatlı yetiştiriciliğinde ayrı bir öneme sahiptir. Çalışmamızda alınan 451 bireysel örnek; 14 adet drag svab, 28 adet pool edilmiş sslak dışk1, 11 adet pool edilmiş embriyolu yumurta, 62 adet pool edilmiş kloakal svab, 3, 4 ve 5'li bir araya gelecek şekilde gruplandırılarak, toplam 115 adet örnekte, hem ISO 6579 kültür metotu hem de geleneksel PCR metotu ile Salmonella aranmıştır. Damızlık yumurtacı tavuklardaki Salmonella yaygınlığı, çalışılan iki metotla da \%18.2 olarak bulunmuştur. Örnek tiplerine bakılarak değerlendirme yapıldığında ise kültür sonuçları; drag svablarda

1 Uludağ Üniversitesi Veteriner Fakültesi Mikrobiyoloji Anabilim Dalı, Görükle Kampüsü, 16059, Bursa, Türkiye. serpilkahya@uludag.edu.tr

2 Uludağ Üniversitesi Veteriner Fakültesi Besin Hijyeni ve Teknolojisi Anabilim Dalı, Görükle Kampüsü, 16059, Bursa, Türkiye. 
$\% 0$, embriyolu yumurtalarda \%90.9, sslak dışkıda \%21.4 ve kloakal svablarda \%8 olarak bulunmuştur. PCR sonuçları da, kültür sonuçları ile örnek tiplerine göre, yine \%100 sensitivite ve spesifite ile aynı bulunmuştur. Türkiye'deki yumurtacı kümeslerde Salmonella yaygınlığı PCR ve ISO 6579 kültür metotları ile \%18.2 olarak bulunmuş ve damızlık kanatlılarda Salmonella taramalarında alınabilecek en güvenli örneklerin embriyolu yumurta ve ıslak dışkı olduğu tespit edilmiştir. Bu sonuçlar aslında, en yüksek oranda Salmonella tespiti yapılan örnek tipinin embriyolu yumurtalar olarak bulunmasıyla, özellikle damızlık yetiştiriciliği yapılan kanatlı sürülerinde, Salmonella teşhisinde güvenilir sonuçlar alınabilmesi için, klasik olarak kullanılan dışkı kökenli örneklerin dışında, farklı örnek tiplerinin de alınarak hep birlikte değerlendirilmesi gerektiğini de göstermiştir. Sonuç olarak, Türkiye'deki yumurtacı tavuk kümeslerinde Salmonella enfeksiyonun önemli problem olarak varlığını sürdürmeyi devam ettiği ve hem geleneksel kültür metotu hem de PCR'ın farklı örneklerden Salmonella tespitinde güvenilir yöntemler olarak kullanılabileceği gösterilmiştir.

Anahtar Kelimeler: Salmonella, damızlık yumurtacı tavuk, polimeraz zincir reaksiyonu (PCR), kültür, zoonoz, farklı örnek tipleri.

\section{Introduction}

Salmonellosis is responsible for about $\% 30$ of all food poisoning cases in the United States $^{28}$ with an estimated 80.3 million annual foodborne cases ${ }^{22}$ in the world, and significant economical losses in poultry sector worldwide. Since poultry is one of the most important reservoirs of Salmonella that can be transmitted to humans through the food-chain, public health concerns have increasingly made the prevention of the foodborne transmission of disease to humans an urgent priority for poultry producers. Poultry and eggs remain the major source of infection in developed countries. Traditional microbiological analysis methods are based on bacterial behavior, such as phenotypic or antibody response, which can present problems with cross reaction among related organisms ${ }^{4}$. In addition, Salmonella serovars are not detectable in certain clinical samples that contain small number of organisms. The standard cultural method for detecting Salmonella require up to 5 days to produce results. To reduce the time required for testing, different methods have been developed ${ }^{8}$ including tests based on novel reagents, yet these tests are generally used to supplement rather than replace existing methods. The exception is the methodology based on PCR, which has progressively been replacing with biochemical and agglutination tests ${ }^{14,30}$. With poultry, control of infection depends largely on the identification of the infection in the early stages.

There are lots of works about different sample type for Salmonella detection ${ }^{4,11,14,15,20,22}$. Cloacal swabs are individual sample and represent the one chicken. Salmonella is disseminated at intervals despite there is an infection, so false negative results can be taken. So, sample type for Salmonella must be represent all the flock for herd health. Furthermore, individual samples (cloacal swab, embryonated chicken egg, organ, etc.) can be taken in such cases, because of vertical transmission and septicemic cases of Salmonella infection, the latter is generally important for typhoid group Salmonella infection ${ }^{4}$.

The objective of this study was to compare the different sample types of the detection for Salmonella by the cultural with International Organization for Standardization (ISO 6579/A1) ${ }^{16}$ and as molecular by PCR methods from chicken layer breeder flocks.

\section{Material and Methods}

\section{Salmonella Strains}

Salmonella enterica subsp. Enterica serovar Enteritidis 64K (M.Y.Popoff, Institut Pasteur, 28 rue du Dr Roux, 75015 Paris Cedex 15, France), Salmonella enterica subsp. Enterica serovar Typhimurium NCTC 12416 (Refik Saydam National Public Health Agency, Ankara, Turkey), Salmonella enterica subsp. Enterica serovar Typhimurium ATCC 14028 and Salmonella enterica subsp. Enterica serovar Enteritidis ATCC 13076 (Uludag University Medical School, Department of Microbiology, Bursa, Turkey) were used as positive controls in PCR and culture.

\section{Clinical Samples}

A total of 115 chicken layer breeder samples, comprised of 451 individual samples each pooled into 3, 4 and 5, including; 14 drag swabs, 28 wet faeces, 11 embryonated chicken eggs, 62 cloacal swabs, were collected from 14 layer flocks, each of the samples were submitted to our laboratory in an ice box within 6 hours after sampling in sterile material and screw-cap plastic bottles. 


\section{Culture}

Bacteriological examination of natural samples was performed as indicated in ISO 6579-A1 (2007) $)^{16}$. For cloacal swabs: swabs from 1 and 5 birds, respectively, were pooled and this pooled sample, which weighed approximately $5 \mathrm{~g}$, were transferred into $45 \mathrm{ml} \mathrm{Buff-}$ ered Peptone Water (BPW, Oxoid, CM1049). For samples: wet faeces and embryonated chicken eggs belonging to 3, 4, 5 and 6 samples, each weighing 6-7 g, were pooled, and this pooled 25 g sample was transferred into $225 \mathrm{~mL}$ BPW. For drag samples: each swab was cutted and weighed $25 \mathrm{~g}$, were transferred into $225 \mathrm{~mL}$ $\mathrm{BPW}$, and incubated at $37^{\circ} \mathrm{C}$ for 18 hours. After this incubation, semisolid Modified Rappaport Vassiliadis Agar (MSRV, Oxoid, CM1112) plates were inoculated with 3 drops (total $0.1 \mathrm{~mL}$ ) of $\mathrm{BPW}$ culture, and incubated at $41.5^{\circ} \mathrm{C}$ for 24 hours. Negative plates were reincubated at $41.5^{\circ} \mathrm{C}$ for 24 hours, and a loopful of growth on MSRV plate was streaked on to both Xylose Lysine Deoxycholate Agar (XLD, Beckton Dickinson, 278850) and Xylose Lysine Tergitol-4 Agar (XLT 4 , Beckton Dickinson, 223420). Also, $0,1 \mathrm{ml}$ from BPW culture were inoculated into Tetrathionate Broth (TTB, Oxoid, CM0029B) and incubated at $37^{\circ} \mathrm{C}$ for 18 hours and was streaked on both XLD and $\mathrm{XLT}_{4}$ Agar. After selective plating at $37^{\circ} \mathrm{C}$ for 24 hours, suspect Salmonella colonies were subjected to biochemical identification by spesific biochemical agar and broths recommended by ISO 6579:2002/Amd 1:2007 (ISO) ${ }^{16}$.

\section{Template Preparation for PCR}

Crude DNA was prepared by modifying the method described by Soumet et al. ${ }^{27}$. One milliliter of TTB culture was centrifuged for 4 min at 4,600 $\mathrm{g}$. The pellet was suspended in $0.85 \%$ saline, was centrifuged, and was resuspended in $20 \mathrm{ml}$ of deionized water. This bacterial suspension was then boiled for $10 \mathrm{~min}$ and was centrifuged for $3 \mathrm{~min}$ at $18,000 \mathrm{~g}$. Five microliters of the supernatant was used as a template in PCR.

\section{PCR primers}

We used Salmonella genus-specific primers 139 and 141 were described by Rahn et al. ${ }^{18}$. The following nucleotide sequences based on the invA gene of Salmonella: 5'-GTG AAA TTA TCG CCA CGT TCG GGC AA-3' and 5'TCA TCG CAC CGT CAA AGG AAC C-3'. Both primers were synthesized in Expedite
DNA synthesizer (Perseptive Biosystems, CA, USA) and were purified using reverse phaseHigh Pressure Liquid Chromatoggraphy (BioCAD700E, Perspective Biosystems, USA).

\section{Polymerase Chain Reaction (PCR)}

The 25- $\mu$ l PCR mixture, which contained $0.3 \mu \mathrm{l}$ of $\mathrm{Taq}$ DNA polymerase $(5 \mathrm{U} / \mu \mathrm{l}), 2.5 \mu \mathrm{l}$ of 10X PCR buffer $(3.5 \mathrm{mM} \mathrm{MgCl} 2), 2.5 \mu \mathrm{l}$ of deoxynucleoside triphosphate (dNTP) mixture $(2 \mathrm{mM}), 1 \mu \mathrm{l}$ of each primer $(5 \mathrm{pmol} / \mu \mathrm{l}), 5 \mu \mathrm{l}$ of template DNA and $12.2 \mu \mathrm{l}$ of deionized water, was taken into small microsantrifuge PCR tubes $(200 \mu 1)$. The expected product size was reported as $284 \mathrm{bp}^{25}$.

PCR reactions were performed using a DNA Air Thermal Cycler, model 1605 (Idaho Technologies). The cycle conditions were as follows: an initial incubation at $94^{\circ} \mathrm{C}$ for $15 \mathrm{~s}$ followed by 30 cycles of denaturation at $94^{\circ} \mathrm{C}$ for $0 \mathrm{~s}$, primer annealing at $50^{\circ} \mathrm{C}$ for $0 \mathrm{~s}$, and primer extension at $72^{\circ} \mathrm{C}$ for $15 \mathrm{~s}$. Following the last cycle, there was a 5 -min incubation at $72^{\circ} \mathrm{C}$. Amplified products were electrophoresed in 1.5 to $2 \%$ agarose gels containing ethidium bromide. A 100 bp DNA ladder was used as molecular size marker.

\section{Results and Discussion}

In this study, we compared different sample types for detection of Salmonella in chicken layer breeder flock with both ISO 6579 culture and PCR method. The overall incidence of Salmonella positivity by ISO culture was found as $18.2 \%$ (21/115) regardless of the sample type. Based on sample types, out of 14 drag swab samples, 0/14 (0\%) were found positive by ISO culture. Out of 62 pooled cloacal swab samples $5 / 62(8.06 \%)$, out of 11 pooled embryonated chicken egg samples 10/11 (90.9\%), out of 28 pooled wet feces samples 6/28 (21.4\%) were found positive, by ISO culture. PCR results were in $100 \%$ agreement (100\% sensitivity and specificity) with culture results for all sample types. These results showed us that embryonated chicken eggs have the most meaningful sample for Salmonella detection from breeder flocks, and the second one was wet feces. 
Table 1: Rate of Salmonella isolation from different samples by International Organization for Standardization Method 6579:2002/AMD 1:2007 (ISO) culture and PCR method

Tablo 1: Farklı örneklerden Salmonella izolasyonu için kullanılan Uluslar arası standartlar örgütü 6579:2002/AMD 1:2007 (ISO) kültür metodu ve PCR yöntemleri sonuçlarının oranları

\begin{tabular}{|l|c|c|c|c|}
\hline \multirow{2}{*}{ Sample type } & \multirow{2}{*}{$\begin{array}{c}\text { Total } \\
\text { samples }\end{array}$} & \multirow{2}{*}{$\begin{array}{c}\text { Number } \\
\text { of pooled } \\
\text { samples }\end{array}$} & \multicolumn{2}{|c|}{$\begin{array}{c}\text { Number of positive } \\
\text { samples by methods }\end{array}$} \\
\cline { 4 - 6 } & & $\begin{array}{c}\text { Culture } \\
\%\end{array}$ & $\begin{array}{c}\text { PCR } \\
\%\end{array}$ \\
\hline Drag swab & 14 & 14 & $0(0)$ & $0(0)$ \\
\hline $\begin{array}{l}\text { Embryonated } \\
\text { chicken egg }\end{array}$ & 45 & 11 & $10(90.9)$ & $10(90.9)$ \\
\hline Wet faeces & 112 & 28 & $6(21.4)$ & $6(21.4)$ \\
\hline Cloacal swab & 280 & 62 & $5(8)$ & $5(8)$ \\
\hline Total & 451 & 115 & $21(18.2)$ & $21(18.2)$ \\
\hline
\end{tabular}

There are similar previous findings from layer flocks for Salmonella detection rates as $0 \%$ to $17 \%^{1,10,11,12,18}$ from our country and as $9.9 \%$ to $17.9 \%$ from other countries ${ }^{15,30}$. Apart from the effects of 'Salmonella prevalence within a flock' ${ }^{2}$ of the housing system ${ }^{7,15}$, and of the flock characteristics ${ }^{23}$, the variations in Salmonella detection rates have particularly been related to the sample type analyzed and the method used ${ }^{2,19,26}$. In our study for instance, embryonated chicken egg and wet feces samples, nonsupported by former study data ${ }^{1,6,11,1218,24}$ seemed to work relatively better for Salmonella detection both than other sample types especially than drag swabs by ISO culture and PCR,. We found the drag swabs Salmonella ratio were $0 \%$ with the same methods. In fact, the intestine is the major site of Salmonella colonization in the chickens after oral infections ${ }^{3}$. Also, in the feces and intestinal content have present many inhibition factors as bilirubin, enzymes etc. ${ }^{20}$. Our previous incidence study ${ }^{29}$ for layer chicken flocks showed that \% 61.0 Salmonella positive from feces with related samples and these result was as high as $55.6 \%, 76.9 \%$ to $86.5 \%$ by Dorn and $\mathrm{Schelif}^{9}, \mathrm{Carl}^{5}$ and $\mathrm{Li}$ et al. ${ }^{21}$ respectively. We speculated that the main reason for this could be due to the low amount of fecal contamination of the cloacal swabs from infected chickens, inhibition from inhibitor factors in the feces and characteristic feature of Salmonella dispersed at intervals. To overcome this hindrance, we recommended the poultry companies to take proper drag swabs with sufficient amount of fecal contamination together with other type samples.

\section{Conclusion}

As a result, by using PCR and ISO culture, we determined that the Salmonella rate in layer flocks in 14 flocks was $18.2 \%$, and that the use of embryonated chicken egg and wet feces samples, respectively in Salmonella detection would yield reliable results than drag and cloacal swabs. For the control of Salmonella infection, selection of sample type and method for diagnosis are important to routine control programs and embryonated chicken eggs must be included the screening for the Salmonella infection, especially for breeding flocks because of vertical transmission of Salmonella infection. Throughout the entire study, continuous detection of Salmonella regardless of the sample type or the year shows that this pathogen is persistently present in the poultry-related environments in Turkey. This indicates that there is still a failure in the application of general precautions or taking biosecurity actions against Salmonella in these areas of concern.

\section{References}

1. Ata Z., Aydin N., 2008. Isolation of Salmonella spp. in Ankara region poultry plants. Veterinary Journal of Ankara University, 55, 161-166.

2. Arnold M.E., Carrique-Mas J.J., Davies R.H., 2010. Sensitivity of environmental sampling methods for detecting Salmonella Enteritidis in commercial laying flocks relative to the withinflock prevalence. Epidemiology and Infection, 138, 330-339.

3. Brownell J.R., Sadler W.W., Fanelli M.J., 1970. Role of caeca in intestinal infection of chicken with Salmonella Typhimurium. Avian Disease, 14, 106-116.

4. Calnek B.W., Barnes H.J., Beard C.W., McDougald L.R., Saif Y.M., 1997. Diseases of Poultry. $10^{\text {th }}$ ed. Iowa State University Press, Ames, USA.

5. Carli K.T., Eyigor A., Caner V., 2001a. Prevalence of Salmonella serovars in chickens in Turkey. Journal of Food Protection, 64,1832-1835.

6. Carli K.T., Unal C.B., Caner V., Eyigor A., 2001b. Detection of Salmonella in chicken feces by a combination of tetrathionate broth enrichment, capillary PCR, and capillary gel electrophoresis. Journal of Clinical Microbiology, 39, 1871-1876.

7. Carrique-Mas J., Breslin M., Snow L., McLaren I., Sayers A.R., Davies R.H., 2009. Persistence 
and clearance of different Salmonella serovars in buildings housing laying hens. Epidemiology Infection, 137, 837-846.

8. De Medici D., Pezzotti G., Marfoglia C., Caciolo D., Foschi G., Orefice L., 1998. Comparison between ICS-VIDAS, MSRV and standard cultural method for Salmonella. International Journal of Food Microbiology, 45, 205-210.

9. Dorn W., Schleiff G., 1997. Evaluation of methods for preparing chicken feces from the veterinary hygienic aspect. Zentralblatt fur Veterinarmedizin Reihe B. 44, 105-118.

10. Eyigor A., Carli K.T., Unal C.B., 2002. Implementation of real-time PCR to tetrathionate broth enrichment step of Salmonella detection in poultry. Letter of Applied Microbiology, 34, 37-41.

11. Eyigor A., Carli K.T., 2003. Rapid detection of Salmonella from poultry by real-time polymerase chain reaction with fluorescent hybridization probes. Avian Diseases, 47, 380-386.

12. Eyigor A., Goncagul G., Gunaydin E., Carli K.T., 2005. Salmonella profile in chickens determined by real-time polymerase chain reaction and bacteriology from years 2000 to 2003 in Turkey. Avian Pathology, 34, 101-105.

13. Gast R.K., 1997. Paratyphoid infections, In Calnek B.W., Barnes H. J., and Beard C.W. (ed.), Diseases of poultry, 12th ed. Iowa State University Press, Ames, Iowa. p. 620-635.

14. Hoorfar J., Cook N., Malorny B., Wagner M., Medici D. De, Abdulmawjood A., Fah P., 2003. Making internal amplification control mandatory for diagnostic PCR. Journal of Clinical Microbiology, 41, 5835.

15. Huneau-Salaün A., Chemaly M., Bouquin S. Le, Lalande F., Petetin I., Rouxel S., Michel V., Fravalo P., Rose N., 2009. Risk factors for Salmonella enterica subsp. enterica contamination in French laying hen flocks at the end of the laying period. Preventive Veterinary Medicine, 271, 89, 51-58.

16. ISO, 2007. Microbiology of food and animal feeding stuffs-horizontal method for the detection of Salmonella (EN ISO 6579:2002/Amd 1:2007). International Organization for Standardization, Geneva, Switzerland.

17. ISO, 2003. Microbiology of food and animal feeding stuffs- 272 protocol for the validation of alternative methods. ISO 16140:2003 (E), International Organization for Standardization, Geneva, Switzerland.

18. Kalender H., Muz A., 1999. Typing of Salmonella species isolated from chickens in Elazig region. Turkish Journal of Veterinary Animal Science, 23, 297-303.

19. Kinde H., Castellan D.M., Kerr D., Campbell J., Breitmeyer R., Ardans A., 2005. Longitudinal monitoring of two commercial layer flocks and their environments for Salmonella enterica serovar Enteritidis and other Salmonella. Avian Disease, 49, 189-194.

20. Kreader C.A, 1995. Design and evalution of Bacteriodes DNA probes for specific detection of human faecal pollution. Applied and Environmental Microbiology, 61, 1171-1179.

21. Li X., Payne J.B., Santos F.B., Levine J. F., Anderson K.E., Sheldon B.W., 2007. Salmonella populations and prevalence in layer feces from commercial high-rise houses and characterization of the Salmonella isolates by serotyping, antibiotic resistance analysis, and pulsed field gel electrophoresis. Poultry Science, 86, 591-597.

22. Majowicz S.E., Musto J., Scallan E., Angulo F.J., Kirk M., O'Brien S.J., Jones T.F., Fazil A., Hoekstra R.M., 2010. The global burden nontyphoidal Salmonella gastroenteritis. Clinical Infectious Disease, 50, 882-889.

23. Namata H., Méroc E., Aerts M., Faes C., Abrahantes J.C., Imberechts H., Mintiens K., 2008. Salmonella in Belgian laying hens: An identification of risk factors. Preventive Veterinary Medicine, 83, 323-336.

24. Nief V., Hoop R.K., 1998. Detection of Salmonella enteritidis in suspected flocks of laying hens. Schweizer Archiv Tierheilkunde, 140, 7075.

25. Rahn K., De Grandis S.A., Clarke R.C., McEwen S.A., Galán J.E., Ginocchio C., III. Curtiss R., Gyles C.L., 1992. Amplification of an invA gene sequence of Salmonella typhimurium by polymerase chain reaction as a specific method of detection of Salmonella. Molecular and Cellular Probes, 6, 271-279.

26. Rybolt M.L., Wills R.W., Byrd J.A., Doler T.P., Bailey R.H., 2004. Comparison of four Salmonella isolation techniques in four different inoculated matrices. Poultry Science, 83, 1112-1116.

27. Soumet C., Ermel G., Rose V., Rose N., Droin P., Salvat G., Colin P., 1999. Identification by a multiplex PCR-based assay of Salmonella Typhimurium and Salmonella Enteritidis strains from environmental swabs of poultry houses. Letters of Applied Microbiology, 29, 1-6.

28. Taitt C.R., Shubin Y.S., Angel R., Ligler F.S., 2004. Detection of Salmonella enterica typhimurium by using a rapid, array-based immunosensor. Applied and Environmental Microbiology, $70,152-158$

29. Temelli S., Kahya S., Eyigör A., Carli K.T., 2010. Incidence of Salmonella Enteritidis in Chicken Layer Flocks in Turkey: Results by Real-Time PCR and ISO Culture Methods. Poultry Science, 89, 1406-1410.

30. Van Hoorebeke S., Van Immerseel F., Schulz J., Hartung J., Harisberger M., Barco L., Ricci A., Theodoropoulos G., Xylouri E., J. Vylder De, 
Ducatelle R., Haesebrouck F., Pasmans F., Kruif A. de, Dewulf J., 2010. Determination of the within and between flock prevalence and identification of risk factors for Salmonella infections in laying hen flocks housed in conventional and alternative systems, Preventetive Veterinary Medicine, 94, 94-100. 